\title{
THE EFFECT OF THE USE OF MINERAL ADDITIVES ON EARLY AND ADVANCED AgE COMPRESSIVE STRENGTH OF High STRENGTH CONCRETES
}

\author{
Ercin GURSEL ${ }^{(1)}$ and Mustafa KAYA ${ }^{(2)}$ \\ ${ }^{(1)}$ Aksaray University, Department of Civil Engineering \\ ${ }^{(2)}$ Assoc. Prof., Aksaray University, Department of Civil Engineering \\ E-Mail : ercingursel@gmail.com, kaya261174@hotmail.com
}

\begin{abstract}
In this study, the effect of using certain proportions of fly ash, Silica fume and milled blast furnace slag instead of cement on the early and final pressure resistances of the high strength concretes has been examined. Within the framework of the experiments, Silica fume has been changed in a ratio of 0-10\%, milled blast furnace slag between 0-50\%, and fly ash between 0-25\% by means of making the usage rates of the aforementioned three different mineral additives. "Water/Binder" rate, which is known to be an important parameter in terms of the compressive strength of concrete, has been changed as 0.20, 0.25 and 0.30 in the context of the experiments, and $100 \times 100 \times 100 \mathrm{~mm}$ cube samples have been taken from the mixtures generated separately for each mineral additive type. This samples 2, 7, 28, 56 and 90-day pressure resistance have been tested.
\end{abstract}

\section{KEYWORDS}

High strength concrete, Fly ash, Milled blast furnace slag, Silica fume, Water/Binder ratio.

\section{INTRODUCTION}

Mineral additives are materials which contain 5-35\% calcium oxide $(\mathrm{CaO})$, and 70-90\% reactive oxides $\left(\mathrm{SiO}_{2}, \mathrm{Al}_{2} \mathrm{O}_{3}, \mathrm{Fe}_{2} \mathrm{O}_{3}\right)$ in them, with pozzolanic features, fine grain (grain size 0-150 $\mu \mathrm{m}$ ), whose natural and artificial forms are found. Artificial mineral additives class comprises of fly ash [1-9], and Silica fume [10-17], and ground granulated blast furnace slag [18- 24]. The reason why they are called artificial arises from the fact that they are not readily found in nature, and that they are obtained during industrial production. The use of artificial mineral additives, each of which is an industrial waste, in concrete and cement has been found based on the works of disposal of these materials. With the increase of the industrial production, the amounts of artificial mineral additives obtained as a by-product also have increased with each passing day, and their storage and disposal began to create big ecological and economic problems. The experts looking for solutions to this problem have examined the artificial mineral additives, and noticed that their contents are very similar to Portland cement. Thanks to this, the use of artificial mineral additives in concrete directly and/or cement additive have been found. As a result of the studies made, it has been observed that the artificial mineral additives used in concrete by replacing with cement in appropriate amounts can give higher pressure resistances compared to concretes produced by using only cement.

The reason why higher pressure resistances are reached in concretes produced with artificial mineral additives used by switching with cement in an appropriate amount is the addition of siliceous, alumina and ferrous $\left(\mathrm{SiO}_{2}, \mathrm{Al}_{2} \mathrm{O}_{3}, \mathrm{Fe}_{2} \mathrm{O}_{3}\right)$ compounds which are largely reactive to 
bindingness unlike cement. These compounds form solid crystals over time by reacting with hydraulic lime $\mathrm{Ca}(\mathrm{OH})_{2}$ released as a result of hydration of cement. [25] At the end of the hydration of cement, C-S-H (Calcium silica hydrate) is generated at a rate of 50-60\%, and $\mathrm{Ca}(\mathrm{OH})_{2}$ in a rate of $20-25 \%$. In the concrete mixture content, the decrease of $\mathrm{Ca}(\mathrm{OH})_{2}$ rate and increase of $\mathrm{C}-\mathrm{S}-\mathrm{H}$ rate undoubtedly improves the concrete pressure resistance. The speed and the amount of resistance that can be obtained by the Portland cement paste in concrete depends on how fast and in what amount the calcium-silicate-hydrate (C-S-H) gels released as a result of the reactions of the calcium silicate main components in cement with water are constituted. The faster the C-S-H gels are generated, the greater the speed of the cement to gain resistance; the more it is generated, the higher is the resistance. [26] Due to the fact that C-S-H rates in the concretes produced by using mineral admixtures are higher compared to the concretes produced with only cement, higher pressure resistances can be achieved.

In the present study we have done, it has been aimed to determine the early and final pressure resistance differences created by fly ash, milled granulated blast furnace slag and Silica smoke used separately by switching with cement in different rates on high strength concretes (HSC). In our TS 13515 - 14 standard, high strength concrete has been defined as "normal or heavy concretes whose pressure resistance class is higher than C50/60 high resistance". Throughout our work, material quality and quality control level has been applied in accordance with the standards mentioned by staying connected to our TS EN 206 - 14 and TS 13515 - 14 concrete standards in order to be able to obtain high strength concrete.

\section{The Effect Of The Mineral Additives On Strength And BINDINGNESS}

Artificial mineral additives are materials with pozzolanic features due to their content, and which cannot provide a sufficient level of bindingness alone. Evaluating on the basis of oxides, they do not have the same binding power despite the fact that their content is quite similar to that of cement. The reason for this is that hydration cannot continue arising from the disproportion of the oxides contained in their content and that its binding components are not in a sufficient amount. In order calcium silica hydrate $(\mathrm{C}-\mathrm{S}-\mathrm{H})$ which is the basic binding to be generated, " $\mathrm{CaO} / \mathrm{SiO}{ }_{2}$ should not be $<2,0$ ". When the Table 3 in which the mineral additive contents are given is examined, it is seen that the value of $\mathrm{CaO} / \mathrm{SiO} 2$ is 0,77 even in MBFS which is the richest mineral additive in terms of $\mathrm{CaO}$. The mineral additives which cannot provide sufficient amount of $\mathrm{CaO}$ on their own in order to generate calcium silica hydrate, provide the required $\mathrm{CaO}$ and $\mathrm{H}_{2} \mathrm{O}$ gain over $\mathrm{Ca}(\mathrm{OH}) 2$ created by $\mathrm{CaO}$, released from the dissolution as a result of uniting with hydration with $\mathrm{Ca}(\mathrm{OH})_{2}$ created as a result of cement hydration, with $\mathrm{H}_{2} \mathrm{O}$ over time. Thanks to this, $\mathrm{Ca}(\mathrm{OH})_{2}$ amount in the concreate decrease, and the $\mathrm{C}-\mathrm{S}-\mathrm{H}$ rate increases. Joining mechanism of mineral admixtures to bindingness is as given below.

The creation of C-S-H and $\mathrm{Ca}(\mathrm{OH})_{2}$ crystals as a result of cement hydration;

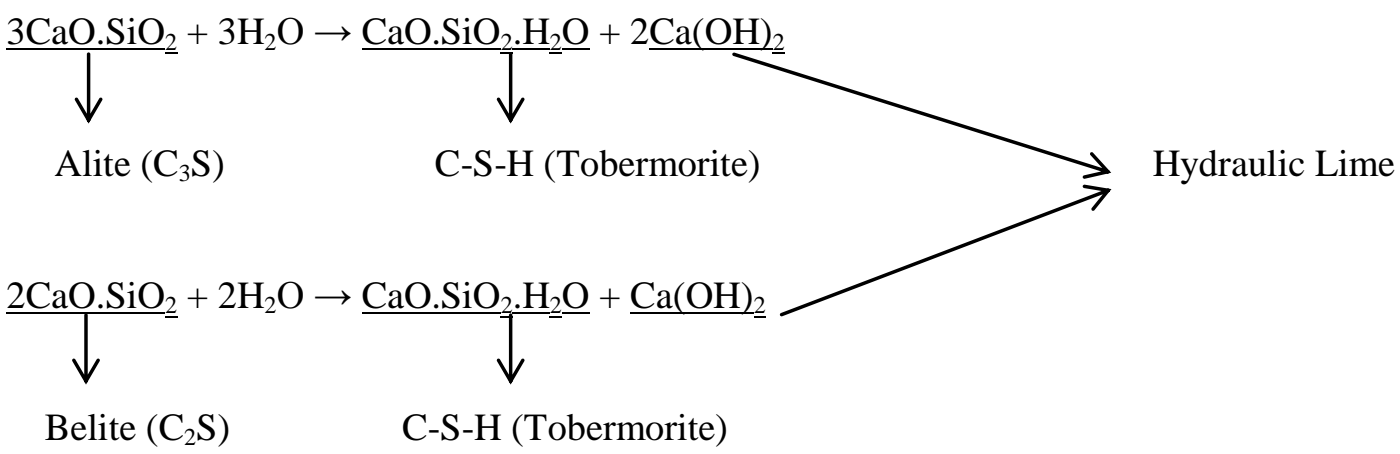


The creation of C-S-H and other hydrate crystals as a result of reaction of the reactive oxides with $\mathrm{Ca}(\mathrm{OH})_{2}$;

$3\left[\mathrm{Ca}(\mathrm{OH})_{2}\right]+2\left[\mathrm{SiO}_{2}\right] \rightarrow \frac{\left[3(\mathrm{CaO}) \cdot 2\left(\mathrm{SiO}_{2}\right) \cdot 3\left(\mathrm{H}_{2} \mathrm{O}\right)\right]}{\mathrm{C}-\mathrm{S}-\mathrm{H}\left(W_{\text {obermorite }}\right)}$

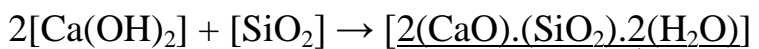

C-S-H (T\&bermorite)

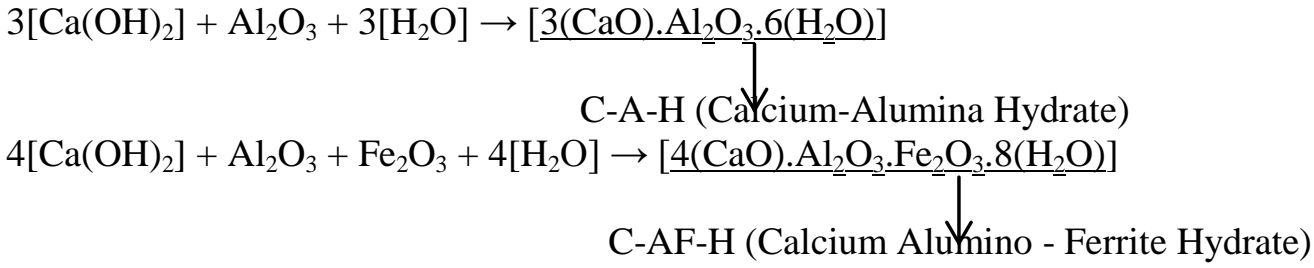

In the concretes in which mineral additive activity has been completed theoretically, there is a decrease in $\mathrm{Ca}(\mathrm{OH})_{2}$ amount, and an increase in the amounts of C-S-H, C-A-H and C-AF-H compounds. Even though the binding and resistance values of the $\mathrm{C}-\mathrm{A}-\mathrm{H}$ and $\mathrm{C}-\mathrm{AF}-\mathrm{H}$ compounds are not as strong as $\mathrm{C}-\mathrm{S}-\mathrm{H}$, they are quite plenty compared to $\mathrm{Ca}(\mathrm{OH})_{2}$. As a result of the completed reactions, the resistance values of the concretes produced by using mineral additives may turn out to be higher compared to concretes produced by only cement. However, it is difficult to say anything definite in terms of the speed of resistance gaining. The reason for this is that, the hydration speed is different according to the combination generated by the binding materials used and the physical properties of materials.

\section{EXPERIMENTAL STUDY}

\subsection{Materials}

\subsubsection{Aggregate}

$\begin{array}{ll}\text { Location } & : \text { Feruz, Ankara } \\ \text { Type } & : \text { Basalt (Massive, Mafic) } \\ \text { Conformity } & : \text { TS 706 EN 12620 +A1 } \\ \mathrm{D}_{\max } & : 16 \mathrm{~mm}\end{array}$

\section{Physical Properties;}

Specific Gravity $\left(\mathrm{gr} / \mathrm{cm}^{3}\right) \quad: 2,91$

Hardness (Mohs) $\quad: 6,5$

Wear (Los A. 500 Cycle, \%) $\quad: 5,0$

Water Absorption (By weight \%) : : 0,7

\subsubsection{Chemical Additive}

Type : İKSA Polycar 300 - Hyper plasticizer

Conformity : TS EN 450-1 


\subsubsection{Mineral Additive}

I. Type Mineral Additive

Type

: Fly Ash - (Çayırhan, Ankara)

: Class F. [27]

Conformity

: TS EN $450-1$

II. Type Mineral Additive

: Milled Blast Furnace Slag - (Payas, Hatay)

Type

: Class 80. [28]

Conformity

: TS EN $15167-1$

III. Type Mineral Additive

: Silica Fume - (Dubai, UAE)

Type

: 1st Class. [29]

Conformity

: TS EN 13263 - 1 +A1

Table 1 : The chemical composition of mineral admixtures.

\begin{tabular}{|lc|c|c|c|}
\hline \multicolumn{2}{|l|}{ Chemical Composition } & M.B.F. Slag & Fly Ash & Silica Fume \\
\hline $\mathrm{SiO}_{2}$ & $(\%)$ & 44,1 & 50,98 & 96,1 \\
\hline $\mathrm{Al2O} 3$ & $(\%)$ & 10,7 & 13,11 & 0,2 \\
\hline $\mathrm{Fe}_{2} \mathrm{O}_{3}$ & $(\%)$ & - & 9,74 & 0,6 \\
\hline $\mathrm{CaO}$ & $(\%)$ & 34,1 & 11,82 & 0,2 \\
\hline $\mathrm{MgO}$ & $(\%)$ & 6,3 & 3,87 & 0,1 \\
\hline $\mathrm{Na}_{2} \mathrm{O}$ & $(\%)$ & - & 2,71 & - \\
\hline $\mathrm{K}_{2} \mathrm{O}$ & $(\%)$ & 0,7 & 1,91 & 0,3 \\
\hline $\mathrm{SO}_{3}$ & $(\%)$ & Sulphur $(\mathrm{S}): 0,4$ & 3,94 & - \\
\hline $\mathrm{FeO}$ & $(\%)$ & 0,3 & - & - \\
\hline $\mathrm{TiO}_{2}$ & $(\%)$ & 0,5 & - & - \\
\hline $\mathrm{Cl}^{-}$ & $(\%)$ & - & 0,01 & - \\
\hline Loss On Ignition & $(\%)$ & 0,04 & 0,86 & 1,81 \\
\hline Insoluble Remains & $(\%)$ & 1,45 & 2,10 & 1,1 \\
\hline
\end{tabular}

Table 2 : Physical properties of the mineral additives.

\begin{tabular}{|c|c|c|c|}
\hline Physical Properties & M.B.F.Slag & Fly Ash & Silica Fume \\
\hline Specific Gravity & 2,82 & 2,34 & 2,25 \\
\hline Specific Surface Area & 4147 & 2758 & 233600 \\
\hline $0,045 \mathrm{~mm}$ Remains Retained in Screen & 8,70 & 29,0 & 0,58 \\
\hline 7-Day Activity & 54 & 61 & 93 \\
\hline 28-Day Activity & 81 & 84 & $>100$ \\
\hline
\end{tabular}




\subsubsection{Cement}

Type : CEM I 42,5R Cement

Conformity : TS EN 197-1

Table 3 : Physical properties of CEM I 42,5R cement.

\begin{tabular}{|lc|c|}
\hline \multicolumn{2}{|l|}{ Physical Properties } & CEM I 42,5R \\
\hline Specific Gravity & $\left(\mathrm{gr} / \mathrm{cm}^{3}\right)$ & 3,10 \\
\hline Specific Surface (Blaine) & $\left(\mathrm{cm}^{2} / \mathrm{gr}\right)$ & 3556 \\
\hline 0,045 mm Remains Retained in Screen & $(\%)$ & 2,1 \\
\hline 0,090 mm Remains Retained in Screen & $(\%)$ & 0,3 \\
\hline 2-Day Pressure Resistance & $\left(\mathrm{N} / \mathrm{mm}^{2}\right)$ & 28,8 \\
\hline 28-Day Pressure Resistance & $\left(\mathrm{N} / \mathrm{mm}^{2}\right)$ & 56,0 \\
\hline
\end{tabular}

\subsection{Mineral Admixtures Usage Experiments}

In the experimental studies, the cement dosage has been determined as $500 \mathrm{~kg} / \mathrm{m} 3$ and the largest water/Binder ratio as 0,30 in order to be able to achieve the required high resistance. The mineral additives have been substituted into the admixture; with increases of $5 \%$ in fly ash, $5 \%$ in milled granulated blast furnace slag and $2 \%$ silica fume. Usage top limits of the mineral additives have been limited in such a way that is compliant with the TS EN $206-14$ and TS 13515 standards. These limits are listed below.

Table 4 : Samples produced using fly ash

\begin{tabular}{|c|c|c|c|c|c|}
\hline \multirow{2}{*}{ Sample Code } & \multicolumn{4}{|c|}{ Amount of Usage (Kg/m $\left.{ }^{3}\right)$} & \multirow{2}{*}{ Water/Binder } \\
\cline { 2 - 6 } & Cement & Fly Ash & $\begin{array}{c}\text { Chemical } \\
\text { Additives }\end{array}$ & Water & \\
\hline Reference -1 & 500 & 0 & 17,0 & 91,5 & 0,20 \\
\hline K1 & 475 & 25 & 17,0 & 88,5 & 0,20 \\
\hline K2 & 450 & 50 & 17,0 & 85,5 & 0,20 \\
\hline K3 & 425 & 75 & 17,0 & 82,5 & 0,20 \\
\hline K4 & 400 & 100 & 17,0 & 79,5 & 0,20 \\
\hline
\end{tabular}


Civil Engineering and Urban Planning: An International Journal(CiVEJ) Vol.3,No.2, June 2016

\begin{tabular}{|c|c|c|c|c|c|}
\hline K5 & 375 & 125 & 17,0 & 76,5 & 0,20 \\
\hline Reference - 2 & 500 & 0 & 12,0 & 119,0 & 0,25 \\
\hline K6 & 475 & 25 & 12,0 & 115,0 & 0,25 \\
\hline K7 & 450 & 50 & 12,0 & 111,0 & 0,25 \\
\hline K8 & 425 & 75 & 12,0 & 108,0 & 0,25 \\
\hline K9 & 400 & 100 & 12,0 & 104,0 & 0,25 \\
\hline K10 & 375 & 125 & 12,0 & 100,0 & 0,25 \\
\hline Reference - 3 & 500 & 0 & 6,0 & 147,0 & 0,30 \\
\hline K11 & 475 & 25 & 6,0 & 142,5 & 0,30 \\
\hline K12 & 450 & 50 & 6,0 & 138.0 & 0,30 \\
\hline K13 & 425 & 75 & 6,0 & 133,5 & 0,30 \\
\hline K14 & 400 & 100 & 6,0 & 129,0 & 0,30 \\
\hline K15 & 375 & 125 & 6,0 & 124,5 & 0,30 \\
\hline
\end{tabular}

Table 5 : Test results of the samples produced using fly ash

\begin{tabular}{|c|c|c|c|c|c|c|c|}
\hline \multirow{2}{*}{ Sample Code } & \multicolumn{5}{|c|}{ Compressive Strength (MPa) } & \multirow{2}{*}{$\begin{array}{c}\text { Standard } \\
\text { Deviation } \\
{\text { (MPa })^{*}}^{\text {(MP }}\end{array}$} & \multirow{2}{*}{$\begin{array}{c}\text { Elasticity } \\
\text { Modulus } \\
(\text { GPa })^{*}\end{array}$} \\
\hline & $\begin{array}{c}2 \\
\text { (Days) }\end{array}$ & $\begin{array}{c}7 \\
\text { (Days) }\end{array}$ & $\begin{array}{c}28 \\
\text { (Days) }^{*}\end{array}$ & $\begin{array}{c}56 \\
\text { (Days) }\end{array}$ & $\begin{array}{c}90 \\
\text { (Days) }\end{array}$ & & \\
\hline Reference - 1 & 45,1 & 67,1 & 95,1 & 98,2 & 101,3 & 0,9 & 40,59 \\
\hline K1 & 44,6 & 65,7 & 95,5 & 102,1 & 105,7 & 1,9 & 40,46 \\
\hline $\mathbf{K} 2$ & 41,1 & 60,4 & 96,4 & 106,0 & 110,3 & 2,1 & 40,72 \\
\hline K3 & 39,7 & 57,0 & 92,2 & 111,2 & 119,5 & 1,7 & 39,49 \\
\hline K4 & 33,4 & 50,4 & 88,8 & 103,7 & 116,3 & 2,4 & 38,98 \\
\hline
\end{tabular}


Civil Engineering and Urban Planning: An International Journal(CiVEJ) Vol.3,No.2, June 2016

\begin{tabular}{|c|c|c|c|c|c|c|c|}
\hline K5 & 29,2 & 46,2 & 85,0 & 104,5 & 120,7 & 1,5 & 38,50 \\
\hline Reference - 2 & 38,6 & 58,0 & 80,1 & 84,5 & 87,2 & 0,5 & 37,43 \\
\hline K6 & 36,1 & 56,8 & 81,6 & 86,1 & 90,4 & 1,6 & 37,67 \\
\hline K7 & 31,6 & 51,2 & 83,5 & 92,1 & 98,5 & 2,2 & 37,81 \\
\hline K8 & 29,2 & 46,3 & 83,2 & 90,5 & 99,9 & 1,4 & 38,02 \\
\hline K9 & 26,5 & 40,1 & 77,1 & 93,6 & 103,3 & 1,6 & 37,23 \\
\hline K10 & 23,0 & 37,2 & 71,1 & 90,7 & 104,0 & 1,2 & 36,20 \\
\hline Reference - 3 & 34,2 & 51,9 & 63,3 & 69,9 & 70,2 & 1,2 & 33,81 \\
\hline K11 & 34,0 & 48,4 & 64,6 & 73,4 & 75,2 & 1,6 & 34,08 \\
\hline K12 & 30,6 & 43,2 & 67,2 & 77,1 & 80,2 & 2,2 & 34,37 \\
\hline K13 & 26,2 & 38,6 & 60,2 & 74,5 & 81,2 & 2,9 & 33,94 \\
\hline K14 & 21,9 & 32,6 & 54,4 & 75,6 & 85,2 & 1,4 & 32,79 \\
\hline 20,4 & 31,7 & 52,6 & 75,1 & 89,5 & 1,9 & 32,91 \\
\hline
\end{tabular}

(*) sign, it means the day of the results of this test.

Table 6 : Samples produced using milled blast furnace slag

\begin{tabular}{|c|c|c|c|c|c|}
\hline \multirow{2}{*}{ Sample Code } & \multicolumn{4}{|c|}{ Amount of Usage (Kg/m $\mathbf{m}^{\mathbf{3}}$} & \multirow{2}{*}{ Water/Binder } \\
\cline { 2 - 5 } & Cement & M.B.F. Slag & $\begin{array}{c}\text { Chemical } \\
\text { Additives }\end{array}$ & Water & \\
\hline Reference -1 & 500 & 0 & 17,0 & 91,5 & 0,20 \\
\hline K16 & 475 & 25 & 17,0 & 90,5 & 0,20 \\
\hline K17 & 450 & 50 & 17,0 & 89,5 & 0,20 \\
\hline K18 & 425 & 75 & 17,0 & 88,5 & 0,20 \\
\hline K19 & 400 & 100 & 17,0 & 87,5 & 0,20 \\
\hline K20 & 375 & 125 & 17,0 & 86,5 & 0,20 \\
\hline K21 & 350 & 150 & 17,0 & 85,5 & 0,20 \\
\hline K22 & 325 & 175 & 17,0 & 84,5 & 0,20 \\
\hline K23 & 300 & 200 & 17,0 & 83,5 & 0,20 \\
\hline K24 & 275 & 225 & 17,0 & 82,5 & 0,20 \\
\hline
\end{tabular}


Civil Engineering and Urban Planning: An International Journal(CiVEJ) Vol.3,No.2, June 2016

\begin{tabular}{|c|c|c|c|c|c|}
\hline K25 & 250 & 250 & 17,0 & 81,5 & 0,20 \\
\hline Reference - 2 & 500 & 0 & 12,0 & 119,0 & 0,25 \\
\hline K26 & 475 & 25 & 12,0 & 118,0 & 0,25 \\
\hline K27 & 450 & 50 & 12,0 & 116,5 & 0,25 \\
\hline K28 & 425 & 75 & 12,0 & 115,0 & 0,25 \\
\hline K29 & 400 & 100 & 12,0 & 114,0 & 0,25 \\
\hline K30 & 375 & 125 & 12,0 & 113,0 & 0,25 \\
\hline K31 & 350 & 150 & 12,0 & 111,5 & 0,25 \\
\hline K32 & 325 & 175 & 12,0 & 110,0 & 0,25 \\
\hline K33 & 300 & 200 & 12,0 & 109,0 & 0,25 \\
\hline K34 & 275 & 225 & 12,0 & 108,0 & 0,25 \\
\hline K35 & 250 & 250 & 12,0 & 106,5 & 0,25 \\
\hline Reference - 3 & 500 & 0 & 6,0 & 147,0 & 0,30 \\
\hline K36 & 475 & 25 & 6,0 & 145,5 & 0,30 \\
\hline K37 & 450 & 50 & 6,0 & 144,0 & 0,30 \\
\hline K38 & 425 & 75 & 6,0 & 142,5 & 0,30 \\
\hline K39 & 400 & 100 & 6,0 & 141,0 & 0,30 \\
\hline K40 & 375 & 125 & 6,0 & 139,5 & 0,30 \\
\hline K41 & 350 & 150 & 6,0 & 138,0 & 0,30 \\
\hline K42 & 325 & 175 & 6,0 & 136,5 & 0,30 \\
\hline K43 & 300 & 200 & 6,0 & 135,0 & 0,30 \\
\hline K44 & 275 & 225 & 6,0 & 133,5 & 0,30 \\
\hline K45 & 250 & 250 & 6,0 & 132,0 & 0,30 \\
\hline
\end{tabular}

Table 7 : Test results of the samples produced using milled blast furnace slag

\begin{tabular}{|c|c|c|c|c|c|c|c|}
\hline \multirow{2}{*}{ Sample Code } & \multicolumn{5}{|c|}{ Compressive Strength (MPa) } & \multirow{2}{*}{$\begin{array}{c}\text { Standard } \\
\text { Deviation } \\
\text { (MPa) }^{*}\end{array}$} & \multirow{2}{*}{$\begin{array}{c}\text { Elasticity } \\
\text { Modulus } \\
\text { (GPa) }^{*}\end{array}$} \\
\hline & $\begin{array}{c}2 \\
\text { (Days) }\end{array}$ & $\begin{array}{c}7 \\
\text { (Days) }\end{array}$ & $\begin{array}{c}28 \\
\text { (Days) }^{*}\end{array}$ & $\begin{array}{c}56 \\
\text { (Days) }\end{array}$ & $\begin{array}{c}90 \\
\text { (Days) }\end{array}$ & & \\
\hline Reference - 1 & 45,1 & 67,1 & 95,1 & 98,2 & 101,3 & 0,9 & 41,22 \\
\hline K16 & 44,8 & 65,5 & 97,8 & 101,6 & 105,4 & 0,8 & 41,78 \\
\hline K17 & 43,2 & 62,6 & 101,4 & 106,3 & 110,7 & 0,6 & 42,00 \\
\hline K18 & 39,7 & 60,2 & 103,2 & 110,9 & 118,1 & 1,7 & 42,17 \\
\hline K19 & 37,4 & 56,3 & 107,9 & 115,0 & 123,5 & 1,2 & 42,52 \\
\hline K20 & 34,2 & 52,2 & 104,0 & 116,5 & 124,2 & 2,4 & 42,47 \\
\hline K21 & 32,6 & 49,6 & 100,3 & 119,1 & 129,2 & 1,7 & 41,79 \\
\hline K22 & 32,4 & 47,8 & 92,2 & 117,3 & 131,6 & 2,6 & 39,93 \\
\hline K23 & 29,9 & 42,3 & 86,7 & 112,2 & 129,0 & 2,1 & 38,72 \\
\hline
\end{tabular}


Civil Engineering and Urban Planning: An International Journal(CiVEJ) Vol.3,No.2, June 2016

\begin{tabular}{|c|c|c|c|c|c|c|c|}
\hline K24 & 24,3 & 38,4 & 78,4 & 105,6 & 123,8 & 1,9 & 37,03 \\
\hline K25 & 23,3 & 35,9 & 73,5 & 98,8 & 119,4 & 2,4 & 36,16 \\
\hline Reference - 2 & 38,6 & 58,0 & 80,1 & 84,5 & 87,2 & 0,5 & 37,43 \\
\hline K26 & 38,2 & 57,2 & 82,0 & 89,2 & 93,5 & 1,4 & 37,94 \\
\hline K27 & 36,1 & 54,1 & 86,9 & 90,6 & 96,0 & 1,7 & 38,84 \\
\hline K28 & 33,4 & 51,9 & 90,2 & 93,2 & 102,1 & 1,2 & 39,45 \\
\hline K29 & 31,9 & 50,5 & 93,6 & 98,5 & 107,5 & 1,1 & 40,06 \\
\hline K30 & 30,0 & 48,2 & 95,1 & 105,7 & 114,0 & 1,9 & 40,23 \\
\hline K31 & 29,2 & 46,2 & 91,3 & 110,2 & 121,5 & 2,0 & 39,77 \\
\hline K32 & 25,2 & 41,6 & 85,0 & 106,4 & 118,8 & 1,6 & 38,70 \\
\hline K33 & 22,7 & 36,2 & 81,1 & 100,0 & 112,9 & 1,0 & 37,88 \\
\hline K34 & 21,3 & 35,1 & 72,7 & 95,1 & 110,9 & 1,9 & 36,49 \\
\hline K35 & 20,1 & 30,7 & 65,4 & 88,0 & 105,6 & 2,1 & 34,66 \\
\hline Reference - 3 & 34,2 & 51,9 & 63,3 & 69,9 & 70,2 & 1,2 & 33,81 \\
\hline K36 & 33,9 & 50,7 & 66,3 & 71,1 & 75,2 & 2,3 & 34,47 \\
\hline K37 & 33,2 & 50,0 & 71,5 & 78,7 & 81,4 & 1,9 & 35,87 \\
\hline K38 & 33,6 & 47,9 & 73,0 & 81,4 & 87,9 & 3,1 & 35,89 \\
\hline K39 & 30,8 & 43,9 & 78,2 & 88,8 & 97,3 & 1,9 & 36,73 \\
\hline K40 & 29,4 & 42,7 & 70,6 & 90,1 & 98,5 & 2,1 & 35,67 \\
\hline K41 & 25,2 & 40,6 & 67,7 & 88,4 & 99,1 & 2,4 & 35,01 \\
\hline K42 & 26,7 & 36,1 & 62,9 & 85,8 & 99,8 & 2,8 & 34,83 \\
\hline K43 & 22,2 & 34,1 & 58,2 & 81,5 & 96,0 & 3,1 & 33,54 \\
\hline K44 & 19,8 & 30,4 & 54,4 & 79,0 & 95,1 & 2,9 & 32,29 \\
\hline K45 & 18,2 & 27,6 & 51,5 & 73,1 & 91,1 & 3,5 & 31,19 \\
\hline
\end{tabular}

Table 8 : Samples produced using silica fume

\begin{tabular}{|c|c|c|c|c|c|}
\hline \multirow{2}{*}{ Sample Code } & \multicolumn{4}{|c|}{ Amount of Usage (Kg/m $\mathbf{3}^{\mathbf{3}}$} & \multirow{2}{*}{ Water/Binder } \\
\cline { 2 - 6 } & Cement & Silica Fume & $\begin{array}{c}\text { Chemical } \\
\text { Additives }\end{array}$ & Water & \\
\hline Reference -1 & 500 & 0 & 17,0 & 91,5 & 0,20 \\
\hline K46 & 490 & 10 & 17,0 & 93,5 & 0,20 \\
\hline K47 & 480 & 20 & 17,0 & 95,5 & 0,20 \\
\hline K48 & 470 & 30 & 17,0 & 97,5 & 0,20 \\
\hline
\end{tabular}


Civil Engineering and Urban Planning: An International Journal(CiVEJ) Vol.3,No.2, June 2016

\begin{tabular}{|c|c|c|c|c|c|}
\hline K49 & 460 & 40 & 17,0 & 99,5 & 0,20 \\
\hline K50 & 450 & 50 & 17,0 & 101,5 & 0,20 \\
\hline Reference - 2 & 500 & 0 & 12,0 & 120,0 & 0,25 \\
\hline K51 & 490 & 10 & 12,0 & 121,5 & 0,25 \\
\hline K52 & 480 & 20 & 12,0 & 124,0 & 0,25 \\
\hline K53 & 470 & 30 & 12,0 & 126,5 & 0,25 \\
\hline K54 & 460 & 40 & 12,0 & 129,0 & 0,25 \\
\hline K55 & 450 & 50 & 12,0 & 131,5 & 0,25 \\
\hline Reference - 3 & 500 & 0 & 6,0 & 147,0 & 0,30 \\
\hline K56 & 490 & 10 & 6,0 & 150,0 & 0,30 \\
\hline K57 & 480 & 20 & 6,0 & 153,0 & 0,30 \\
\hline K58 & 470 & 30 & 6,0 & 156,0 & 0,30 \\
\hline K59 & 460 & 40 & 6,0 & 159,0 & 0,30 \\
\hline K60 & 450 & 50 & 6,0 & 162,0 & 0,30 \\
\hline
\end{tabular}

Table 9 : Test results of the samples produced using silica fume

\begin{tabular}{|c|c|c|c|c|c|c|c|}
\hline \multirow{2}{*}{ Sample Code } & \multicolumn{5}{|c|}{ Compressive Strength (MPa) } & \multirow{2}{*}{$\begin{array}{c}\text { Standard } \\
\text { Deviation } \\
\text { (MPa) }^{*}\end{array}$} & \multirow{2}{*}{$\begin{array}{c}\text { Elasticity } \\
\text { Modulus } \\
\text { (GPa) }^{*}\end{array}$} \\
\hline & $\begin{array}{c}2 \\
\text { (Days) }\end{array}$ & $\begin{array}{c}7 \\
\text { (Days) }\end{array}$ & $\begin{array}{c}28 \\
(\text { Days) }\end{array}$ & $\begin{array}{c}56 \\
\text { (Days) }\end{array}$ & $\begin{array}{c}90 \\
\text { (Days) }\end{array}$ & & \\
\hline Reference - 1 & 45,1 & 67,1 & 95,1 & 98,2 & 101,3 & 0,9 & 41,22 \\
\hline K46 & 45,4 & 67,9 & 96,0 & 101,3 & 105,2 & 1,5 & 41,18 \\
\hline K47 & 45,2 & 69,2 & 99,6 & 104,0 & 108,3 & 1,1 & 41,96 \\
\hline K48 & 44,4 & 70,3 & 103,3 & 108,1 & 111,7 & 2,2 & 43,14 \\
\hline
\end{tabular}


Civil Engineering and Urban Planning: An International Journal(CiVEJ) Vol.3,No.2, June 2016

\begin{tabular}{|c|c|c|c|c|c|c|c|}
\hline K49 & 43,7 & 71,6 & 106,2 & 110,9 & 112,5 & 3,0 & 43,76 \\
\hline K50 & 42,1 & 73,1 & 108,4 & 114,2 & 117,6 & 2,1 & 44,05 \\
\hline Reference - & 38,6 & 58,0 & 80,1 & 84,5 & 87,2 & 0,5 & 37,43 \\
\hline K51 & 37,1 & 60,2 & 83,6 & 88,2 & 90,2 & 1,9 & 38,45 \\
\hline K52 & 36,8 & 61,7 & 85,1 & 91,5 & 94,7 & 2,1 & 39,21 \\
\hline K53 & 34,7 & 65,2 & 86,8 & 93,8 & 96,3 & 1,4 & 39,08 \\
\hline K54 & 34,5 & 68,0 & 90,3 & 97,9 & 101,3 & 1,8 & 40,13 \\
\hline K55 & 33,1 & 69,1 & 93,9 & 99,6 & 104,0 & 2,3 & 40,63 \\
\hline Reference - 3 & 34,2 & 51,9 & 63,3 & 69,9 & 70,2 & 1,2 & 33,81 \\
\hline K56 & 34,4 & 54,6 & 64,6 & 73,2 & 75,2 & 1,6 & 34,65 \\
\hline K57 & 34,9 & 57,2 & 68,2 & 75,7 & 81,4 & 0,7 & 35,03 \\
\hline K58 & 33,6 & 57,7 & 73,9 & 79,2 & 86,2 & 1,5 & 36,70 \\
\hline K59 & 33,0 & 60,5 & 76,7 & 82,4 & 87,3 & 2,0 & 37,07 \\
\hline
\end{tabular}

(*) sign, it means the day of the results of this test.

The limit value for fly ash: "the maximum amount of fly ash that will be used together with CEM I cement" included in the (2) article of the headline " $k$-value for the fly ash that is compliant with 5.2.5.2.2 EN 450-1" of TS 13515 standard must provide the condition given below: (Fly ash / cement ) $\leq 0,33$ (as mass)".[6a]

The limit value for ground granulated blast furnace slag: When "Annex L" section of TS EN 206 - 14 standard is examined, this expression is seen in an article (7); "the maximum amount of ground granulated blast furnace slag: (as mass) ground blast furnace slag/cement $\leq 1,0$ ". This expression is valid for CEM I cement.[6b]

The limit value for Silica fume: "the maximum amount of Class 1 Silica smoke that will be taken into consideration must meet the following requirement: (Silica fume/cement) $\leq 0,11$ (as mass)" included in the article (2). of the headline " $\mathrm{k}$-value for the class 1 silica fume that is compliant with 5.2.5.2.3 EN 13263-1" of the TS 13515 standard. This expression is valid for CEM I cement.[7]

When Table 4 is examined, it is seen that fly ash/cement (as mass) rate of the K5, K10, and K15 samples is 0,333 . However, it is seen that this situation provides the requirement of tolerance 
value " $\pm \% 3$ " for the acceptable mineral additive usage error for high strength concretes included in the section "Chart 27" of the TS EN 206 - 14 standard. The same situation is also valid for the K50, K55, K60 admixtures produced by using silica fume.

\section{ASSESSMENT OF THE EXPERIMENT RESULTS}

\subsection{Assessment of the Admixture Results with Fly Ash Substitute}

In concretes with high strength, class $\mathrm{F}$ fly ash used by switching with cement in certain ratios within the measurements allowed by our standards;

$\rightarrow$ When it is used up to $10 \%$, it reduces the 2 and 7-day resistances of the prepared samples compared to the witness samples (replicate samples), however, increases the $28+$ day final resistance strengths to higher levels.

$\rightarrow 2,7$ and 28-day fly ash usage in a rate of $\% 15-25$ reduces the resistances of the prepared samples compared to the witness samples (replicate samples), however this situation changes in 56+ day resistances, and reaches higher levels compared to the witness samples (replicate samples).

$\rightarrow$ The effect of the general resistance gain of the fly ash in $0.20,0.25$ and 0.30 water/binder rates does not change and provides compliance to the first two articles above.

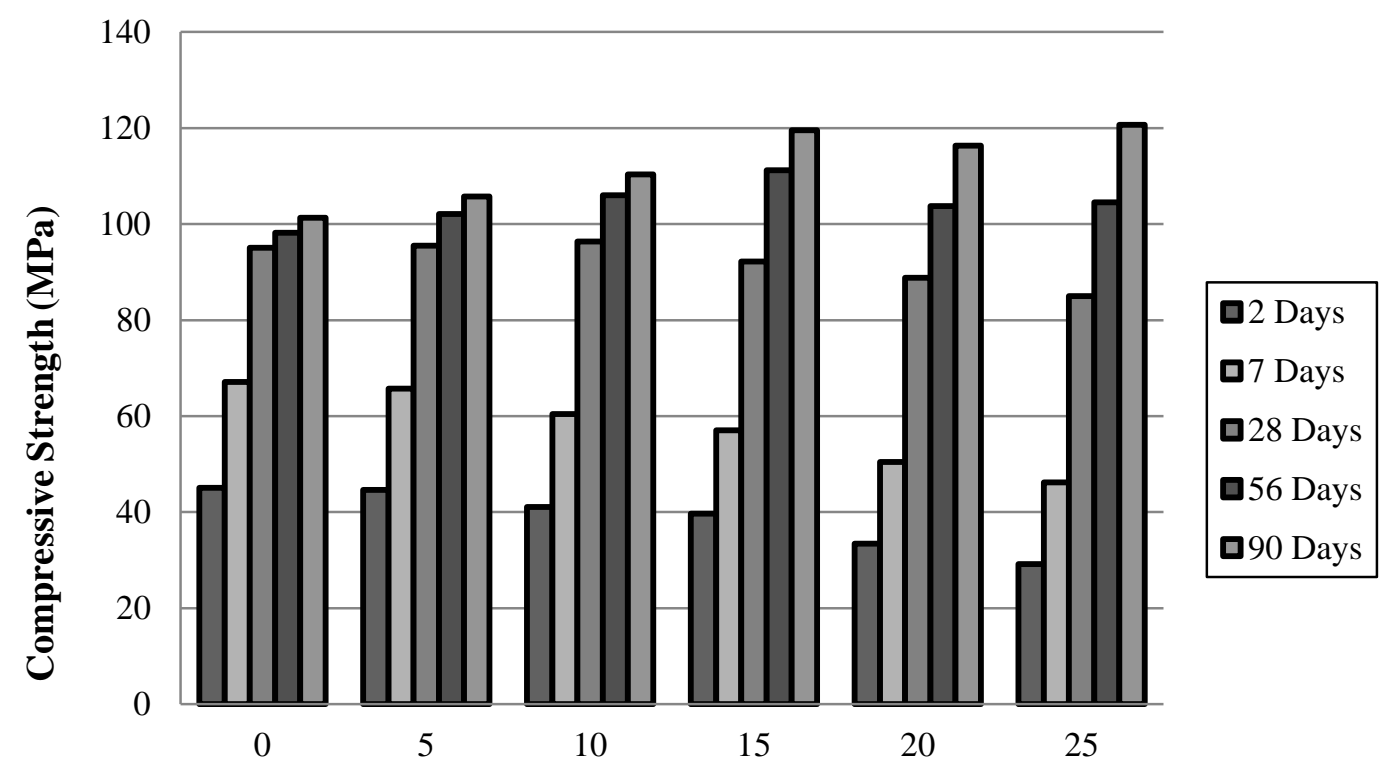

Fly Ash Substitute Rate (\%)

Figure 1 : Time-dependent variation of pressure resistance of the fly ash substitutes samples with a water/binder ration of 0,20 . 


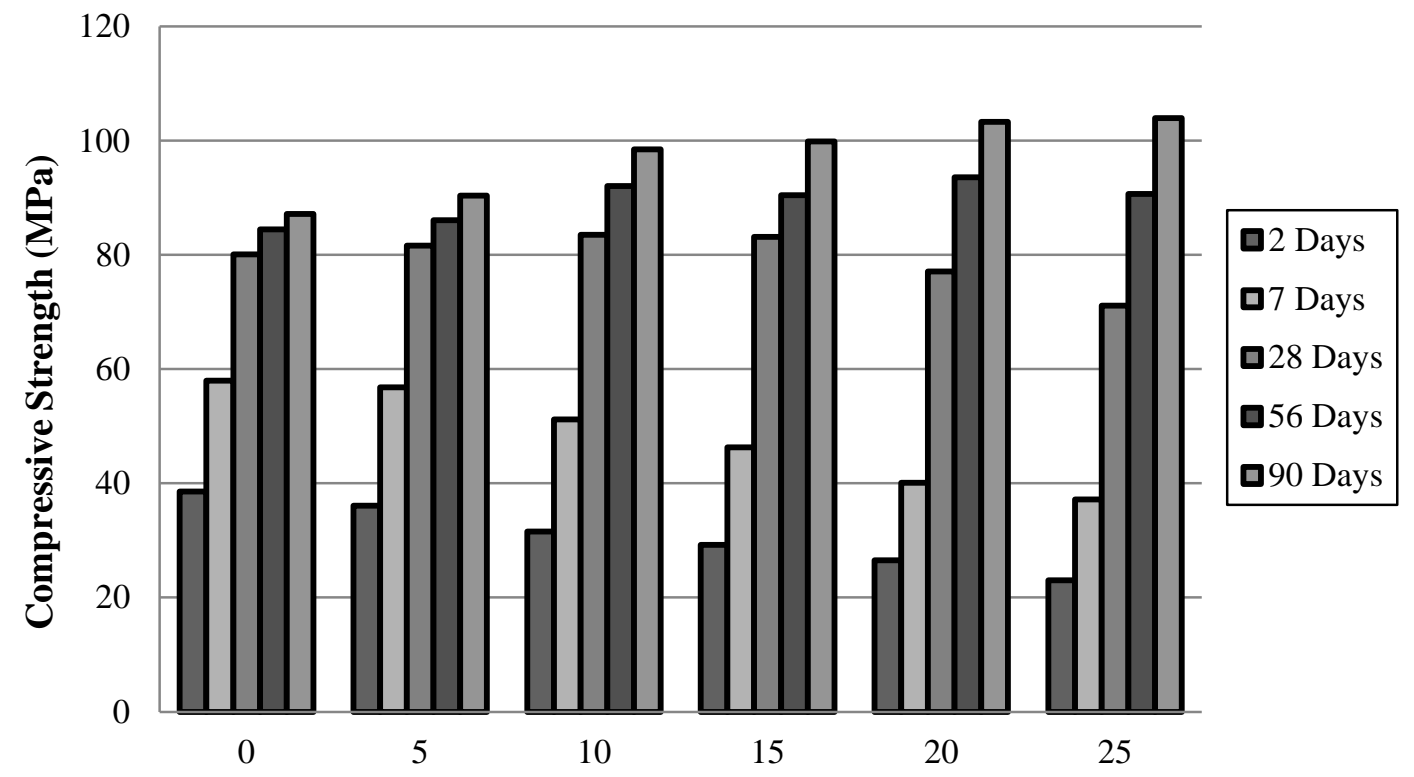

Fly Ash Substitute Rate (\%)

Figure 2: Time-dependent variation of pressure resistance of the fly ash substitutes samples with a water/binder ration of 0,25 .

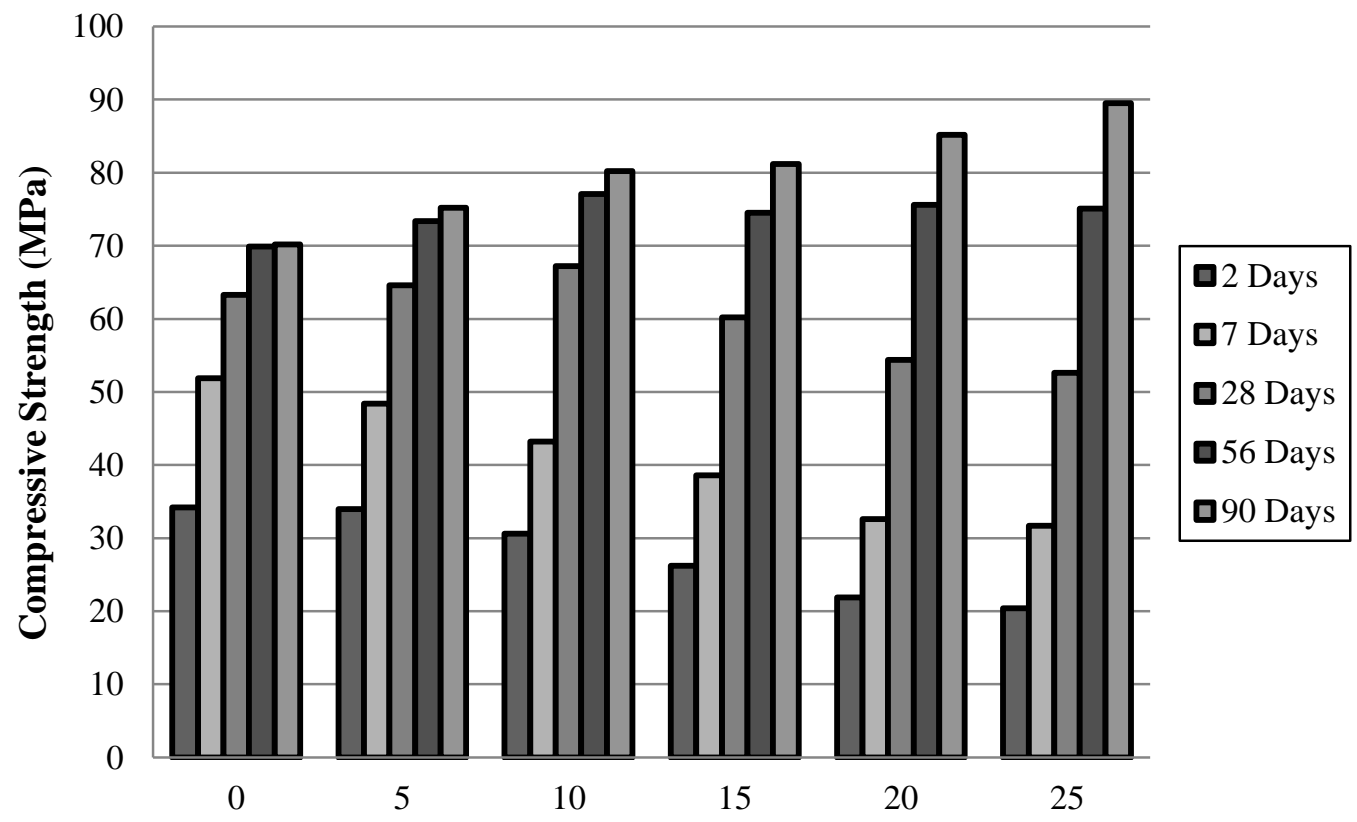

Fly Ash Substitute Rate (\%)

Figure 3: Time-dependent variation of pressure resistance of the fly ash substitutes samples with a water/binder ration of 0,30 .

\subsection{Assessment of the Admixture Results with Milled Blast Furnace Slag Substitute}

In concretes with high strength, class 80 Milled Blast Furnace Slag used by switching with cement in certain ratios within the measurements allowed by our standards; 
$\rightarrow$ When it is used up to $30 \%$, it reduces the 2 and 7-day resistances of the prepared samples compared to the witness samples (replicate samples), however, increases the $28+$ day final resistance strengths to higher levels.

$\rightarrow 2,7$ and 28-day fly ash usage in a rate of \%35-50 reduces the resistances of the prepared samples compared to the witness samples (replicate samples), however this reaches higher levels in 56+ day resistances.

$\rightarrow$ The effect of the general resistance gain of the milled blast furnace slag (MBFS) in 0.20, 0.25 and 0.30 water/binder rates does not change and provides compliance to the first two articles above.

$\rightarrow$ Milled blast furnace slag, because it contains up to $35 \% \mathrm{CaO}$, the mixture is used instead of cement into offers up to $30 \%$ higher compared to the reference values in the 28 -day compressive strength.

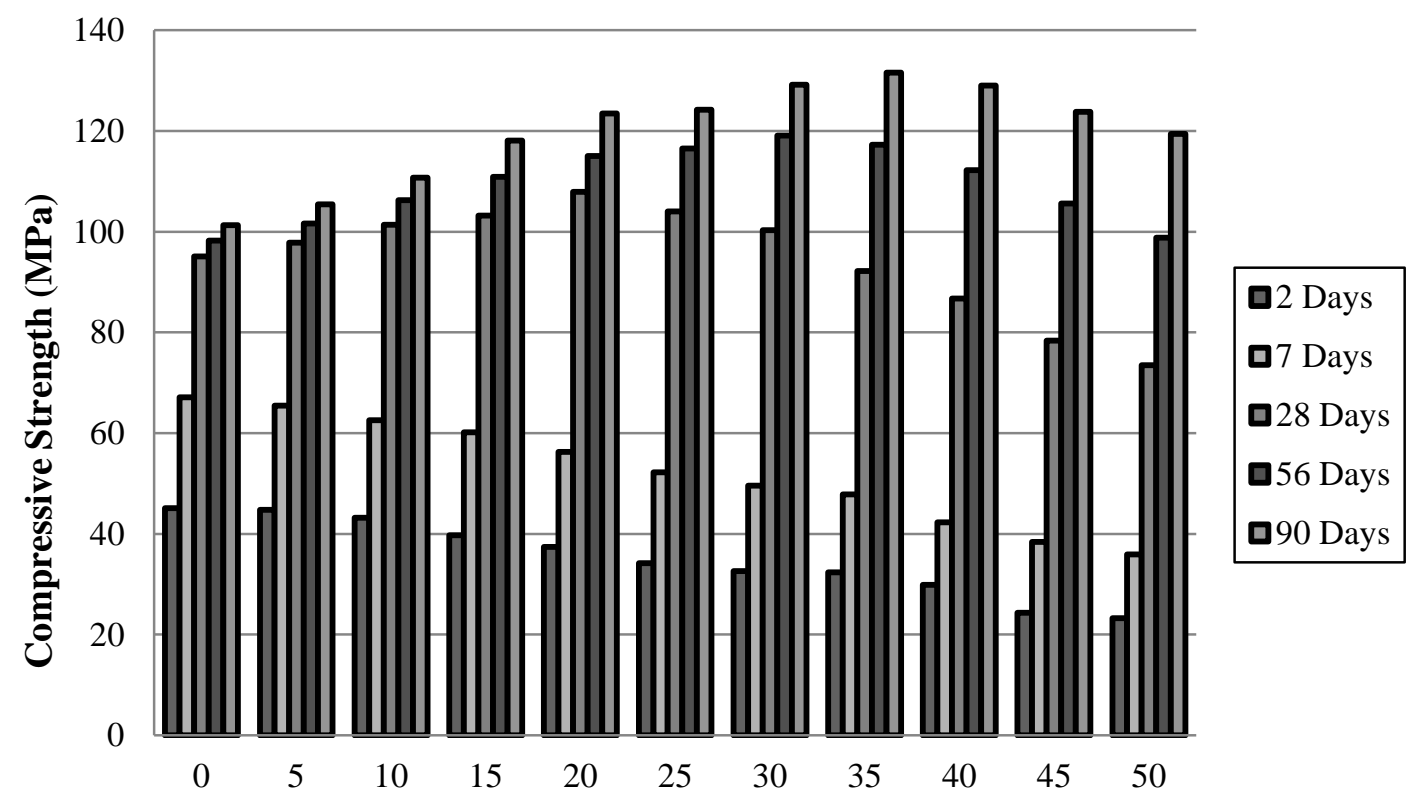

Milled Blast Furnace Slag Substitute Rate (\%)

Figure 4: Time-dependent variation of pressure resistance of the milled blast furnace slag substitutes samples with a water/binder ration of 0,20 . 


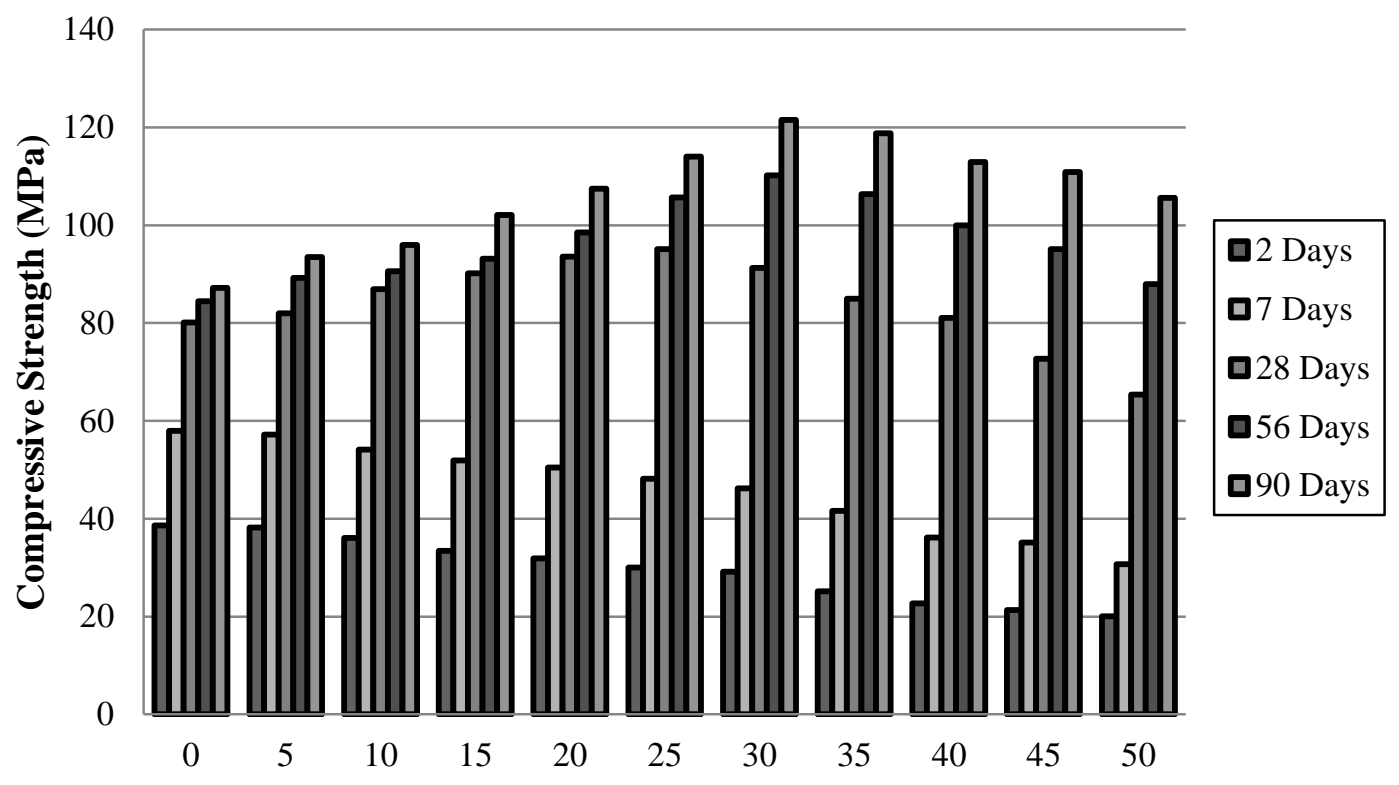

Milled Blast Furnace Slag Substitute Rate (\%)

Figure 5: Time-dependent variation of pressure resistance of the milled blast furnace slag substitutes samples with a water/binder ration of 0,25 .

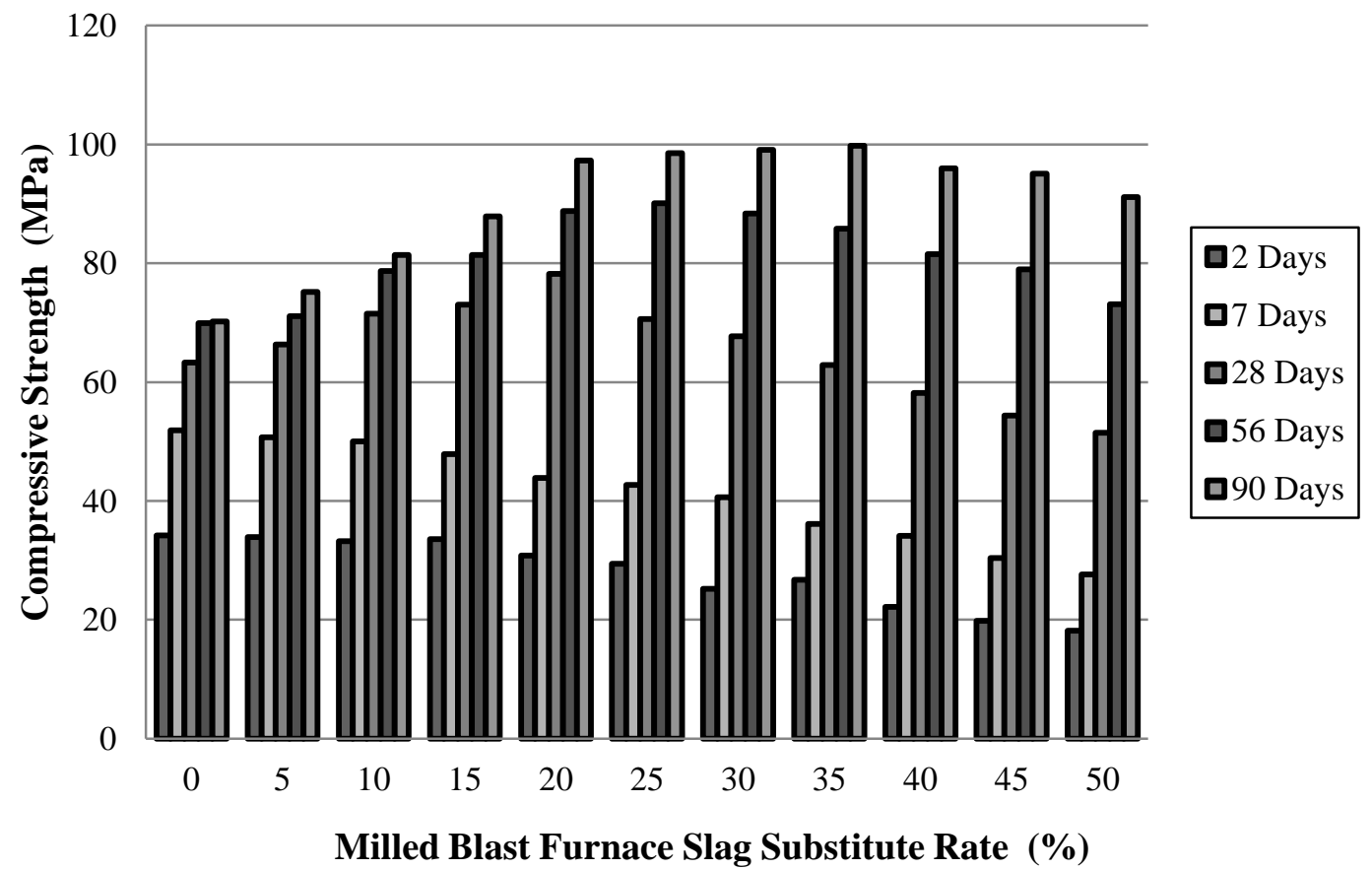

Figure 6: Time-dependent variation of pressure resistance of the milled blast furnace slag substitutes samples with a water/binder ration of 0,30 .

\subsection{Assessment of the Admixture Results with Silica Fume Substitute}

In concretes with high strength, 1st class silica fume used by switching with cement in certain ratios within the measurements allowed by our standards; 
$\rightarrow$ When it is used up to $10 \%$, it reduces only the 2-day resistances of the prepared samples compared to the witness samples (replicate samples), however, increases the 7+ day final resistance strengths compared to the witness samples to higher levels.

$\rightarrow$ The effect of the $0.20,0.25$ and 0.30 water/binder rates of silica fume usage on the general resistance gain do not change, and provides compliance with the first article above.

$\rightarrow$ The silica fume ( Silica fume / cement ) $\leq 0.11$ (as mass) utilization rate , the reason for giving strength loss early age, a high proportion of $\mathrm{SiO}_{2}$, and that the surface area of the silica fume is thought to be due to very large. High levels of $\mathrm{SiO} 2$, a significant increase in the rate of pozzolanic reaction resulting from $\mathrm{C}-\mathrm{S}$ - $\mathrm{H}$ gel constitute . C- S- $\mathrm{H}$ in the mixture of the increase of the gel, provides a higher compressive strength is obtained.

$\rightarrow$ Silica fume is very high surface area, at an early age in the concrete mix provides to contribute to the show pozzolanic reaction and compressive strength .

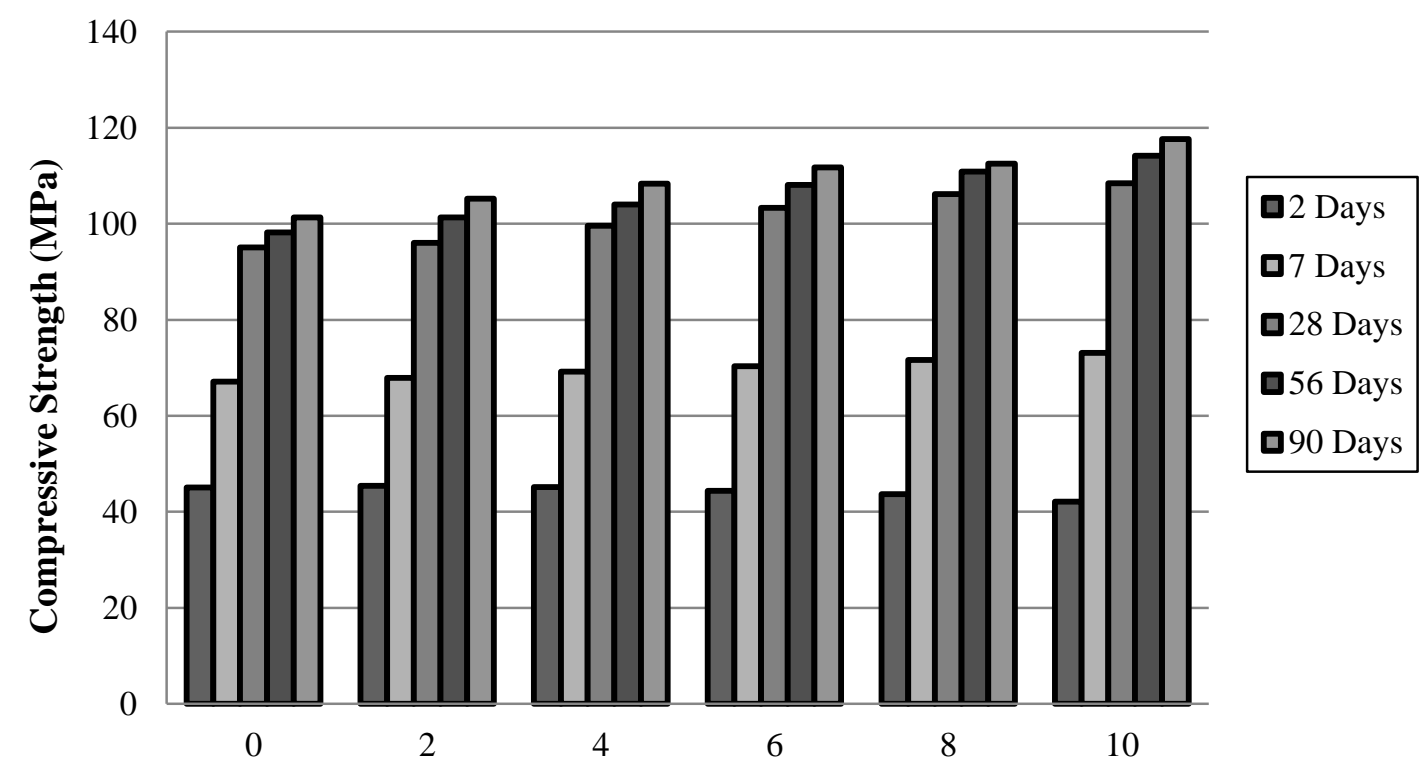

Silica Fume Substitute Rate (\%)

Figure 7: Time-dependent variation of pressure resistance of the silica fume substitutes samples with a water/binder ration of 0,20 . 


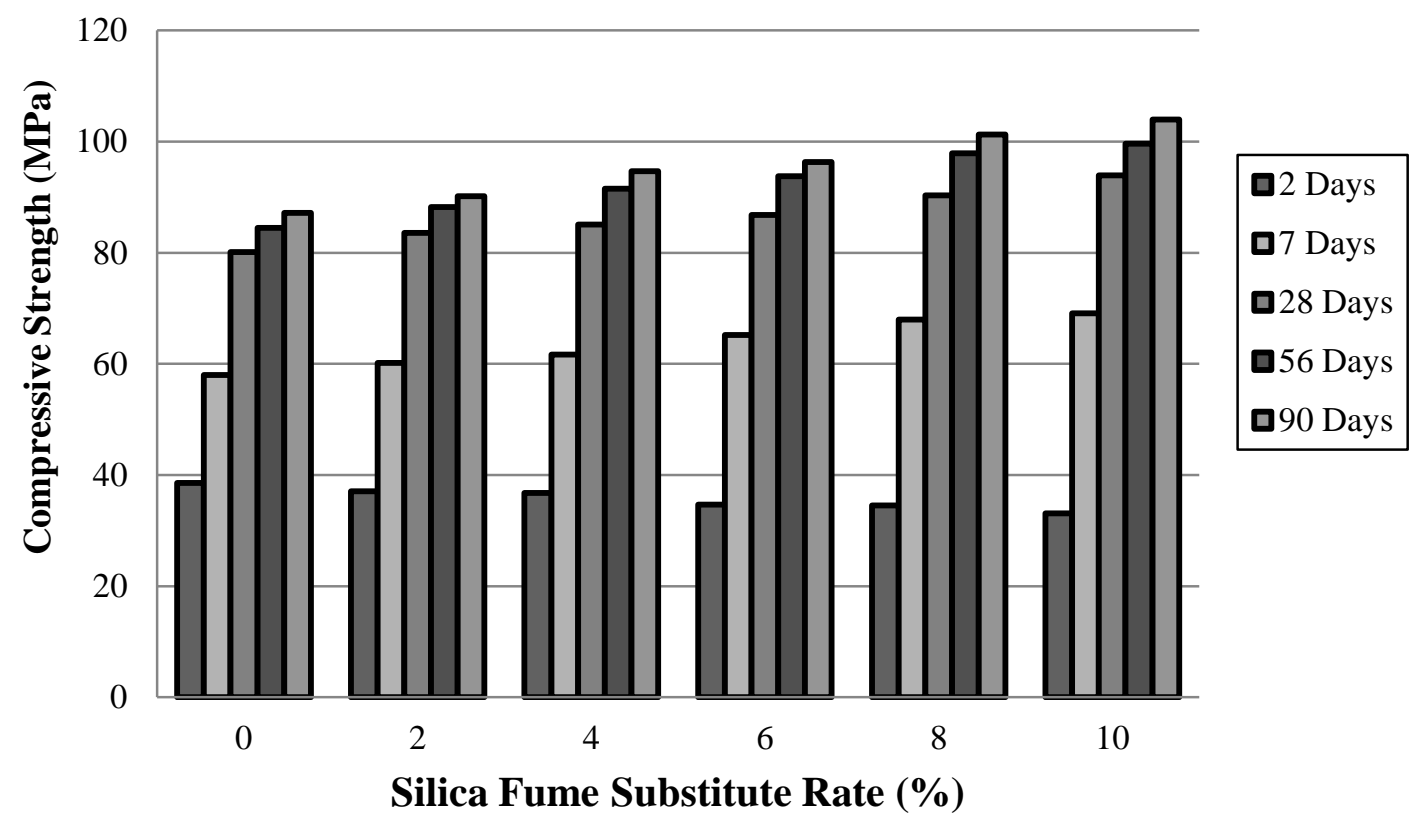

Figure 8: Time-dependent variation of pressure resistance of the silica fume substitutes samples with a water/binder ration of 0,25 .

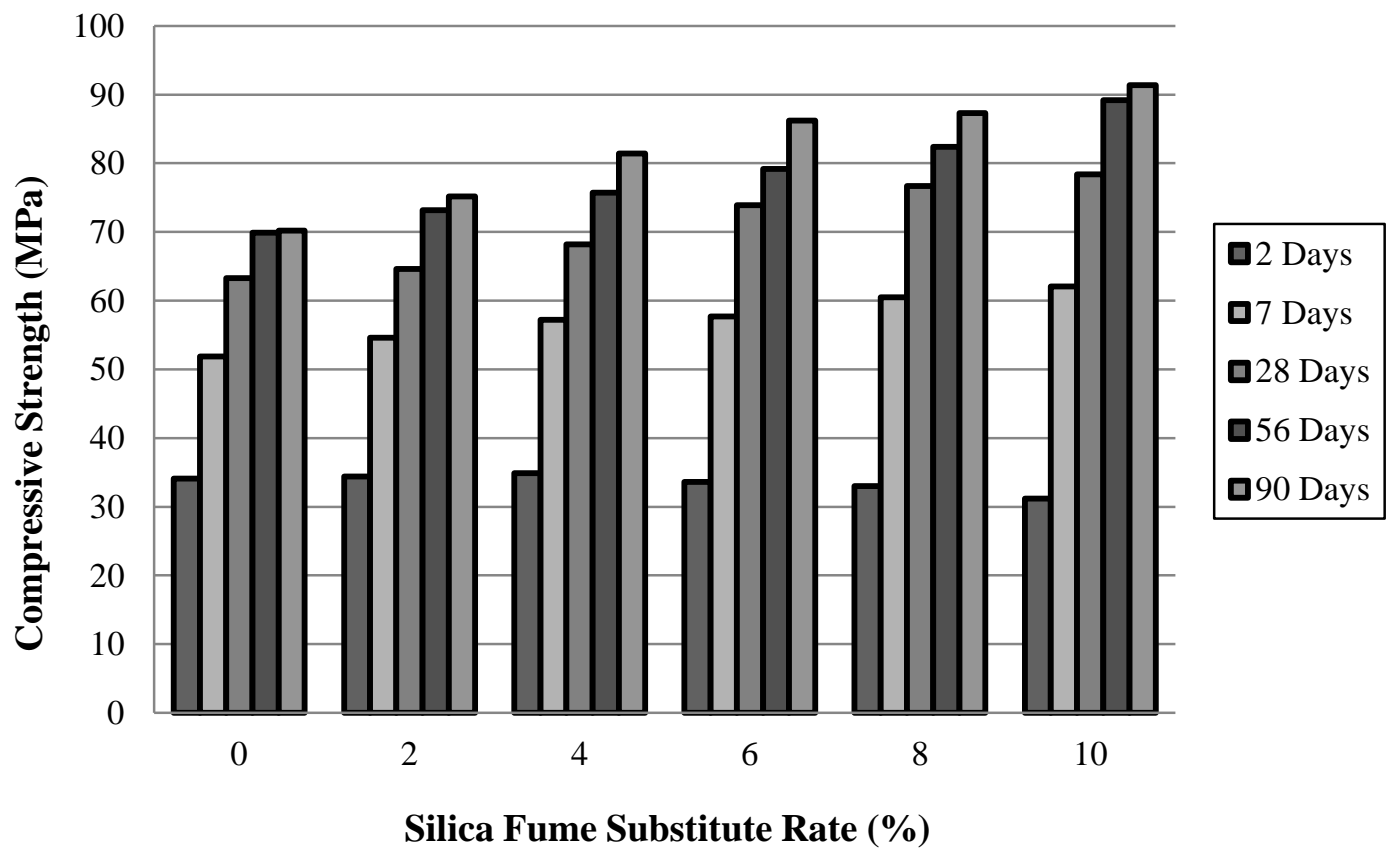

Figure 9: Time-dependent variation of pressure resistance of the silica fume substitutes samples with a water/binder ration of 0,30 . 


\section{RESULTS AND RECOMMENDATIONS}

It is seen that, remaining in the limit values of the material amounts (mineral additives, chemical additives) of the TS EN 206-14 and TS 13515 standards we already use, complying with the specified quantity in material usage and quality control levels, it is possible to produce highstrength concrete with resistances such as $73.1 \mathrm{MPa}, 108.4 \mathrm{MPa}, 119.1 \mathrm{MPa}, 131.6 \mathrm{MPa}$ respectively in 7, 28, 56 and 90-day $100 \times 100 \times 100 \mathrm{~mm}$ cube strengths. In particular, it is possible to carry these figures to higher levels by reducing the $\mathrm{D}_{\max }$ value and increasing the amount of binder material. Mineral additives increase the $\mathrm{Ca}(\mathrm{OH})_{2}$ amount in the concrete, and enables the concrete to become more stable and to display outstanding resistance properties against external effects. The contents of the admixtures prepared within the framework of the experiments have been analyzed in the "Life-365" program, and it has been observed that in the HSC with water/binder $\leq 0,30$, mineral additive usage up to $35 \%$ is able to lengthen the concrete service life up to $60 \%$ under ideal conditions. Other benefits of mineral additive usage apart from the mechanical properties of the high strength concretes have been listed below;

- The fact that they are industrial wastes each and their being consumed by being used in high strength concretes is of great importance in terms of the concept of "Sustainability".

- By reducing the amount of cement needed, by reducing the $\mathrm{CO}_{2}$ emissions arising from the production of cement and the consumption of raw materials, benefits are obtained to a great extent in terms of ecological balance.

- Their being used without being stored gives rise to a great economic and ecological profit in terms of their disposal.

- Their reducing the need for cement offers a plus the advantage economically.

Based on the test results and the information provided, mineral additive usage by replacing with the appropriate amount of cement in normal and high-strength concrete is recommended by the authors. Experimental studies should be done and the results should be evaluated before using mineral additives.

\section{REFERENCES}

[1] Hubbard. F.H, Pulverized Fly Ash for Concrete: Compositional Characterization of UK PFA, Cement and Concrete Research, C.15, s.185-198 No.1, 1985

[2] Enders. M, The $\mathrm{CaO}$ Distribution to Mineral Phases in a High Calcium Fly Ash from Eastern Germany, Cement and Concrete Research, C.26, No.2, s.243-250, 1996.

[3] Mehta. K, Influence of Fly Ash Characteristics on the Strength of Portland-Fly Ash Mixtures, Cement and Concrete Research C.15, No.1, s.669-674, 1985.

[4] Tikalsky, P.J, and Carraqullo, R.L, Influence of Fly Ash on Sulfate Resistance of Concrete, ACI Materials Journal, C.89, No.1, s.69-75, 1992.

[5] Bosbach, D. and Enders, M, Microphotography of High Calcium Fly Ash Particle Surfaces, Advances in Cement Research, C.10, No.1, s.17-24,1998.

[6] Diamond. S, Particle Morphologies in Fly Ash,Cement and Concrete Research,C.16, No.4, s.569-579, 1986.

[7] Tanosaki. T, Characterization of Incineration Ashes in Japan, Journal of Research of the Chichibu Onoda Cement Corp., C.49, No.135, s.145-154, 1998

[8] Cabrera. J.G, The Use of Classified Fly Ash to Produce High Performance Concrete, Sixth Canmet/ACI İnt. Conf. On Fly Ash, Silica Fume, Slag and Pozzolans in Concrete, Bangkok, C.1,s.2126, 1998.

[9] Mora. E.P, Influence of Different Sized Fractions of a Fly Ash on Workability of Mortars, Cement and Concrete Research, C.23, No.4, s.917-924, 1993.

[10] Aköz, F., Koral, S., Yuzer, N., Turker, F., 1995. Effects of sodium sulfate concentration on the sulfate resistance of mortars with and without silica fume, Cement and Concrete Research, 25 (6) 1995, 1360-1368. 
[11] Aköz, F., Turker, F., Koral, S., Yuzer, N., 1999. Effects of raising the temperature of sulfate solutions on the sulfate resistance of mortars with and without silica fume, Cement and Concrete Research, 29 (4) 537-544.

[12] Hooton, R.D., 1993. Influence of Silica Fume Replacement of Cement on Physical Properties and Resistance to Sulfate Attack, Freezing and Thawing and Alkali- Silica Reactivity, ACI Materials Journal. 90, 2, 143-151.

[13] Jahren, P., 1993. Use of Silica Fume in Concrete, ACI SP-79. 1, 625-642.

[14] Kanda, T., Sakuramoto, F., Suzuki, K., 1992. Compressive Strength of Silica Fume Concrete at Higher Temperatures, ACI SP-132. 2, 1089-1103.

[15] Khayat, K.H., Aitcin, P. C., 1992. Silica Fume in Concrete -An Overview, ACI SP-132. 2, 835-872.

[16] Mehta, P. K., 1985. Chemical attack of low water cement ratio concretes containing latex or silica fume as admixtures, ACI/RILEM, Symposium on Technology of Concrete When Pozzolans, Slags and Chemicals are Used, Monterrey, Mexico, March, 1985, pp.325-340.

[17] Tautanji, A. H., Bayasi, Z., 1999. Effect of curing procedures on properties of silica fume concrete, Cement and Concrete Research, 29 (4) 1999, 497-501.

[18] Celik, T, Marar, K., "Effect of Crushed Stone Dust on Some Properties of Concrete", Cement and Concrete Research, Vol. 26, No 7, pp 1121-1130.

[19] Pal, S.C, Mukherjee, A, Pathak S.R, Investigation of Hydralic Activity of Ground Granulated Blast Furnace Slag in Concrete, Cement and Concrete Research, Vol. 23, pp. 1-6, 2003.

[20] Mantel, D.G, Investigation of hydraulic activity of five granulated blast furnace slags with eight different portland cement, ACI Material Journal, Vol. 91, No 5, pp 471-477, 1994.

[21] Satarin, V.I, Slag portland Cement, Proceeding 6th International Congress on the Chemistry of the Cement, Moscow, 1974, Principal Paper, pp 1-51. 810

[22] Malhotra, V.M, Properties of fresh and hardened concrete incorporating ground granulated blast furnace slag, Supplementary Chemistry Materials for Concrete”, Ottawa, pp 231-331, 1987.

[23] Neville, A.M, Properties of Concrete, 4th Edition, Longman 1999.

[24] Donza, H., Cabrera, O., Irasser, E.F, High Strenght Concrete with Different Fine Aggregate, Cement and Concrete Research, Vol 27, No 17. pp 1-7, 2002.

[25] Yalçın, H. and Guru, M., (2006) "Cement and concrete”, Palme publishing, Ankara, pp 44-45.

[26] Erdoğan, T., (2013) "Concrete" , ODTU geliştirme vakfı yayıncılık ve iletim A.S. Development Foundation Publishing and Transmission Corp.), METU, Ankara, pp 148.

[27] ASTM C618 - 05, (2005) "Coal Fly Ash and Raw or Calcined Natural Pozzolan for Use in Concrete".

[28] ASTM C989 - 06, (2006) "Ground Granulated Blast-Furnace Slag for Use in Concrete and Mortars".

[29] ASTM C1240 - 05, (2006) "Silica Fume Used in Cementitious Mixtures".

[30] TS EN 206 - 14, (2014) "Concrete-Properties, performance, production and conformity".

[31] TS 13515, (2014) "Complementary standard for the implementation of TS EN 206". 